\title{
Advances in the genetics of primary torsion dystonia
} Enza Maria Valente ${ }^{1,2}$ and Alberto Albanese ${ }^{3,4 *}$

\author{
Addresses: ${ }^{1}$ CSS-Mendel Institute, viale Regina Margherita 261, 00198 Rome, Italy; ${ }^{2}$ Department of Medical and Surgical Pediatric Sciences, \\ University of Messina, Via Consolare Valeria, 98124 Messina, Italy; ${ }^{3}$ Fondazione IRCCS Istituto Neurologico Carlo Besta, Via Celoria 11, 20133 \\ Milan, Italy; ${ }^{4}$ Università Cattolica del Sacro Cuore, Largo Gemelli 1, 20123 Milan, Italy \\ *Corresponding author: Alberto Albanese (alberto.albanese@unicatt.it) \\ FI000 Biology Reports 2010, 2:4I (doi:10.34I0/B2-4I)
}

The electronic version of this article is the complete one and can be found at: http://fl000.com/reports/biology/content/2/4 I

\begin{abstract}
Knowledge about the genetics of primary torsion dystonia (PTD) has been progressing at a very slow pace compared with other movement disorders. For many years, only one causative gene was known, DYTI/TORIA, yet the recent identification of a second PTD causative gene (DYT6/THAPI), the detection of subclinical alterations caused by mutations in PTD genes in some healthy nonpenetrant individuals, and functional studies on TORIA and THAPI protein products have significantly improved mutation detection, genotype-phenotype correlates, and our understanding of the cellular mechanisms underlying the development of dystonia.
\end{abstract}

\section{Introduction and context}

Torsion dystonias are characterized by involuntary muscle contractions that result in repetitive movements and abnormal postures. The term 'primary torsion dystonia' (PTD) usually refers to pure primary forms characterized by dystonia alone [1] (Table 1), yet this term has also been employed with a more extensive meaning to describe all forms of primary dystonias, although such usage is discouraged [2]. Pure PTD (hereafter referred to simply as PTD) can be further divided based on the age of onset (early onset being variably defined as beginning between the ages of 20 and 30 years) and distribution of dystonia (which can be focal, segmental, or generalized). Familial aggregation is more common in early-onset forms, which also present a higher propensity to generalize, whereas late-onset PTD is often sporadic and tends to remain focal or segmental in distribution $[1,3]$.

For several years, only one gene causative of autosomal dominant PTD has been known: the DYT1/TOR1A gene [4]. DYT1 dystonia is caused in nearly all cases by a GAG deletion in exon 5 of TOR1A and is typically characterized by early onset in a limb, generalization, and a tendency to spare the cranial-cervical muscles $[5,6]$. There is markedly reduced penetrance (only $30 \%$ of mutation carriers actually develop the disease in their life) and wide phenotypic variability even within families; atypical phenotypes, including late-onset, focal, or segmental dystonia phenotypes with cranialcervical involvement, have been reported $[7,8]$.

\section{Major recent advances \\ The DYT6/THAPI gene}

In 2009, Fuchs and colleagues [9] identified THAP1 (thanatos-associated protein domain-containing apoptosis-associated protein 1 ) as the second gene causative of autosomal dominant PTD. The THAP1 gene encodes a protein characterized by a conserved putative DNAbinding motif, a proline-rich region, and a large coiledcoil region that includes a nuclear localization domain. Deleterious mutations were first identified in four ancestrally related Amish-Mennonite families and in a fifth, unrelated family of German ancestry. Subsequently, THAP1 heterozygous mutations were identified in 9 out of $36(25 \%)$ DYT1-negative families with early-onset non-focal PTD [10]. This high mutation frequency was not confirmed by other studies that reported an overall prevalence of about $1.0-2.5 \%$ in PTD cohorts variably selected on the basis of family history, early onset, generalization, or involvement of 
Table I. Primary pure dystonia genes/loci according to the DYT nomenclature

\begin{tabular}{|c|c|c|c|}
\hline Disease (OMIM) & Gene/locus & Phenotype & Transmission \\
\hline DYTI (I28100) & TORIA & Generalized early-limb-onset dystonia & AD \\
\hline DYT2 (224500) & Unknown & Early-onset generalized dystonia with prominent cranial-cervical involvement & AR \\
\hline DYT4 (I2810I) & Unknown & Whispering dysphonia & AD \\
\hline DYT6 (602629) & THAPI & Generalized cervical and upper-limb-onset dystonia & AD \\
\hline DYT7 (602I24) & $18 p$ & Adult-onset cervical dystonia & $A D$ \\
\hline DYTI3 (60767I) & Ip36.13-36.32 & Cervical and upper-limb dystonia & AD \\
\hline DYTI7 (6I2406) & $20 p|1.2-q| 3.12$ & Segmental or generalized dystonia with prominent dysphonia & AR \\
\hline
\end{tabular}

AD, autosomal dominant; AR, autosomal recessive; OMIM, Online Mendelian Inheritance in Man [32].

the laryngeal or cervical regions (or both) [11-14]. The THAP1 phenotype typically presents with early-onset dystonia that differs from DYT1 dystonia in the frequent involvement of the cranial-cervical district. In particular, speech is commonly affected because of oro-mandibular dystonia or laryngeal dystonia (or both). Interestingly, THAP1 was recently found mutated also in sporadic cases with focal or segmental dystonia involving the cervical or laryngeal district that started in the patients' fifth or sixth decade, suggesting that this gene may also play a role in the pathogenesis of late-onset, focal/segmental PTD $[14,15]$. As for DYT1/TOR1A, THAP1 mutations are also associated with reduced penetrance, with healthy mutation carriers identified in several families.

\section{Tackling PTD complexity: in pursuit of penetrance modifiers and endophenotypes}

The low penetrance and variable phenotypic expression associated with mutations in DYT1 and DYT6 genes represent the complexity of PTD genetics well, calling for the identification of genetic modifiers even in these monogenic forms. Among the most common forms of late-onset focal or segmental dystonia, clinical examination of first-degree relatives detected a positive family history in up to $25 \%$ of patients [16]. These findings support the hypothesis that PTD represents a truly complex disorder in which several genetic variants of low penetrance variably co-occur with environmental factors that affect the development and phenotypic manifestation of the disease.

In search of penetrance modifiers in DYT1 dystonia, a large study on a cohort of American subjects carrying the pathogenic GAG deletion showed that the frequency of the TOR1A coding variant D216H in trans with the deletion (e.g., on the other allele) was increased in healthy mutation carriers and decreased in affected subjects compared with controls, suggesting a relevant role for this variant in regulating penetrance of DYT1-PTD [17]. Two subsequent studies on GermanItalian and French DYT1 mutation carriers, respectively, gave rise to contrasting results, the first one supporting and the second arguing against the original findings $[18,19]$. At present, the role of this variant requires confirmation, and the mechanisms underlying reduced penetrance of DYT1 and DYT6 mutations remain to be understood.

In this scenario, the identification of novel diseaseassociated genes is hampered by the scarcity of large families with several affected members and the difficulty to pool homogeneous families for linkage purposes or groups of patients for association studies.

An interesting approach to overcome these limitations is the identification of endophenotypes, which are subclinical traits related to a specific genetic background (i.e., a pathogenetic mutation in a PTD gene) detectable also in healthy individuals who are nonpenetrant carriers of the mutation. Indeed, several studies have reported the presence of subclinical abnormalities in healthy carriers of DYT1 or DYT6 mutations by neuroimaging (positron emission tomography, voxel-based morphometry, diffusion tensor magnetic resonance imaging) $[20,21]$, neurophysiological (cortical and spinal inhibition, temporal discrimination, body movement representation) [22-24], and expression profiling approaches [25]. In light of these findings, similar approaches have been employed to detect possible endophenotypes among healthy relatives of patients with familiar forms of focal dystonia, in which the major causative gene is still unknown. In particular, a recent study correlated an altered temporal discrimination threshold detected in some healthy family members of dystonic patients with structural putaminal abnormalities detected by voxel-based morphometry, supporting the usefulness of this endophenotypic trait and its potential relevance in genetic studies [26].

\section{Future directions}

Given that the first PTD gene was discovered in 1997 [4], the identification of new dystonia genes has 
progressed at a very slow pace compared with advancements in the field of non-primary dystonias and other movement disorders (such as Parkinson disease). The TOR1A protein product, TorsinA, is a member of the AAA1 superfamily of ATPases associated with a variety of cellular activities. This superfamily of chaperone proteins performs critical functions related to protein degradation, membrane trafficking, vesicle fusion and organelle movement, cytoskeletal dynamics, and correct folding of proteins $[27,28]$. TorsinA is almost ubiquitously expressed, and its expression in the brain is restricted to neurons, where it is associated with the endoplasmic reticulum (ER). In cellular models expressing the pathogenic GAG deletion, mutant TorsinA is redistributed from the ER lumen to the nuclear envelope (NE) [29]. These cells also display abnormal morphology and thickening of the NE, including altered connections between the inner and outer membranes, and generation of whorled membrane inclusions that appear to 'spin off' the ER and NE. These inclusions are associated with the vesicular monoamine transporter VMAT2, a finding that might functionally relate TorsinA to the dopaminergic system [30]. In addition, TorsinA has been found to regulate cellular trafficking of the dopamine transporter and other membrane-bound proteins. It has also been shown that the mutant TorsinA interferes with cytoskeletal events that may affect the development of neuronal pathways in the brain and that it is prematurely degraded by both the proteasome and macroautophagy pathways [31].

THAP1, instead, is a member of a family of cellular factors sharing a highly conserved DNA-binding THAP domain, which is an atypical zinc finger, and can regulate endothelial cell proliferation. A proposed disease mechanism is that DYT6 mutations may disrupt THAP1 binding to DNA and produce transcriptional dysregulation. Although the mechanism underlying dysfunction of the THAP1 protein in DYT6 dystonia is not known in the same detail as that of TorsinA, these two genetic disorders are capable of producing comparable motor abnormalities that likely underlie a similar disruption of communication within the basal ganglia. The availability of a second PTD gene will provide new insights into the pathophysiology of this very peculiar movement disorder and allow investigators to perform comparative functional studies to identify shared pathways leading to the development of dystonia. In particular, we expect that functional imaging studies will be able to further identify shared as well as different patterns of activation/deactivation of brain areas in patients with DYT1 and DYT6 dystonia, highlighting their specific role in the pathogenesis of these forms of PTD. There is great need for specific molecular models which could explain the underlying pathogenetic mechanisms shared by different genetic forms.

\section{Abbreviations}

ER, endoplasmic reticulum; NE, nuclear envelope; PTD, primary torsion dystonia; THAP1, thanatosassociated protein domain-containing apoptosis-associated protein 1 .

\section{Competing interests}

The authors declare that they have no competing interests.

\section{References}

I. Albanese A, Asmus F, Bhatia K, Elia EA, Elibol B, Filippini G, Gasser T, Krauss JK, Nardocci N, Newton A, Valls-Solé J: EFNS guidelines on diagnosis and treatment of primary dystonias. Eur $J$ Neurol 2010, [Epub ahead of print].

2. Muller U: The monogenic primary dystonias. Brain 2009, I32:2005-25.

3. de Carvalho Aguiar PM, Ozelius LJ: Classification and genetics of dystonia. Lancet Neurol 2002, I:316-25.

4. Ozelius LJ, Hewett JW, Page CE, Bressman SB, Kramer PL, Shalish C, de Leon D, Brin MF, Raymond D, Corey DP, Fahn S, Risch NJ, Buckler AJ, Gusella JF, Breakefield XO: The early-onset torsion dystonia gene (DYTI) encodes an ATP-binding protein. Nat Genet 1997, 17:40-8.

5. Bressman SB, Sabatti C, Raymond D, de Leon D, Klein C, Kramer PL, Brin MF, Fahn S, Breakefield X, Ozelius LJ, Risch NJ: The DYTI phenotype and guidelines for diagnostic testing. Neurology 2000, 54:1746-52.

6. Fasano A, Nardocci N, Elia AE, Zorzi G, Bentivoglio AR, Albanese A: Non-DYTI early-onset primary torsion dystonia: comparison with DYTI phenotype and review of the literature. Mov Disord 2006, 21:|4|I-8.

7. Edwards M, Wood N, Bhatia K: Unusual phenotypes in DYTI dystonia: a report of five cases and a review of the literature. Mov Disord 2003, 18:706-II.

8. Gambarin M, Valente EM, Liberini P, Barrano G, Bonizzato A, Padovani A, Moretto G, Fiorio M, Dallapiccola B, Smania N, Fiaschi A, Tinazzi M: Atypical phenotypes and clinical variability in a large Italian family with DYTI-primary torsion dystonia. Mov Disord 2006, 21 : 1782-4.

9. Fuchs T, Gavarini S, Saunders-Pullman R, Raymond D, Ehrlich ME, Bressman SB, Ozelius LJ: Mutations in the THAPI gene are responsible for DYT6 primary torsion dystonia. Nat Genet 2009, 4I:286-8.

FI000 Factor 3.0 Recommended

Evaluated by Alejandro Schaffer 09 Feb 2009

10. Bressman SB, Raymond D, Fuchs T, Heiman GA, Ozelius LJ, SaundersPullman R: Mutations in THAPI (DYT6) in early-onset dystonia: a genetic screening study. Lancet Neurol 2009, 8:44I-6.

II. Djarmati A, Schneider SA, Lohmann K, Winkler S, Pawlack H, Hagenah J, Brüggemann N, Zittel S, Fuchs T, Raković A, Schmidt A, Jabusch HC, Wilcox R, Kostić VS, Siebner H, Altenmüller E, Münchau A, Ozelius LJ, Klein C: Mutations in THAPI (DYT6) and generalised dystonia with prominent spasmodic dysphonia: a genetic screening study. Lancet Neurol 2009, 8:447-52.

12. Bonetti M, Barzaghi C, Brancati F, Ferraris A, Bellacchio E, Giovanetti A, lalongo T, Zorzi G, Piano C, Petracca M, Albanese A, Nardocci N, Dallapiccola B, Bentivoglio AR, Garavaglia B, Valente EM: 
Mutation screening of the DYT6/THAPI gene in Italy. Mov Disord 2009, 24:2424-7.

13. Paisán-Ruiz C, Ruiz-Martinez J, Ruibal M, Mok KY, Indakoetxea B, Gorostidi A, Massó JF: Identification of a novel THAP I mutation at R29 amino-acid residue in sporadic patients with early-onset dystonia. Mov Disord 2009, 24:2428-9.

14. Houlden H, Schneider SA, Paudel R, Melchers A, Schwingenschuh P, Edwards M, Hardy J, Bhatia KP: THAPI mutations (DYT6) are an additional cause of early-onset dystonia. Neurology 2010, 74:846-50.

FI000 Factor 3.0 Recommended Evaluated by Jonathan Mink 23 Apr 2010

15. Xiao J, Zhao Y, Bastian RW, Perlmutter JS, Racette BA, Tabbal SD, Karimi M, Paniello RC, Wszolek ZK, Uitti RJ, Van Gerpen JA, Simon DK, Tarsy D, Hedera P, Truong DD, Frei KP, Dev Batish S, Blitzer A, Pfeiffer RF, Gong S, LeDoux MS: Novel THAP I sequence variants in primary dystonia. Neurology 2010, 74:229-38.

16. Martino D, Aniello MS, Masi G, Lamberti P, Lucchese V, Lamberti S, Livrea P, Berardelli A, Defazio G: Validity of family history data on primary adult-onset dystonia. Arch Neurol 2004, 6I:1569-73.

17. Risch NJ, Bressman SB, Senthil G, Ozelius LJ: Intragenic Cis and Trans modification of genetic susceptibility in DYTI torsion dystonia. Am J Hum Genet 2007, 80: I I88-93.

18. Kamm C, Fischer H, Garavaglia B, Kullmann S, Sharma M, Schrader C, Grundmann K, Klein C, Borggraefe I, Lobsien E, Kupsch A, Nardocci N, Gasser T: Susceptibility to DYTI dystonia in European patients is modified by the $\mathrm{D} 216 \mathrm{H}$ polymorphism. Neurology 2008, 70:226I-2.

19. Frédéric MY, Clot F, Blanchard A, Dhaenens CM, Lesca G, Cif L, Dürr A, Vidailhet $M$, Sablonniere B, Calender A, Martinez M, Molinari N, Brice A, Claustres M, Tuffery-Giraud S, CollodBeroud G: The p.Asp2 I6His TORIA allele effect is not found in the French population. Mov Disord 2009, 24:919-21.

20. Carbon M, Eidelberg D: Abnormal structure-function relationships in hereditary dystonia. Neuroscience 2009, 164:220-9.

21. Argyelan M, Carbon M, Niethammer M, Ulug AM, Voss HU, Bressman SB, Dhawan V, Eidelberg D: Cerebellothalamocortical connectivity regulates penetrance in dystonia. J Neurosci 2009, 29:9740-7.

22. Fiorio M, Gambarin M, Valente EM, Liberini P, Loi M, Cossu G, Moretto G, Bhatia KP, Defazio G, Aglioti SM, Fiaschi A, Tinazzi M: Defective temporal processing of sensory stimuli in DYTI mutation carriers: a new endophenotype of dystonia? Brain 2007, I30:134-42.

23. Fiorio M, Gambarin M, Defazio G, Valente EM, Stanzani C, Moretto G, Loi M, Soliveri P, Nardocci N, Albanese A, Fiaschi A, Tinazzi M: Impaired body movement representation in DYTI mutation carriers. Clin Neurophysiol 2008, I 1 9: 1864-9.

24. Edwards MJ, Huang YZ, Wood NW, Rothwell JC, Bhatia KP: Different patterns of electrophysiological deficits in manifesting and non-manifesting carriers of the DYTI gene mutation. Brain 2003, I 26:2074-80.

25. Walter M, Bonin M, Pullman RS, Valente EM, Loi M, Gambarin M, Raymond D, Tinazzi M, Kamm C, Glöckle N, Poths S, Gasser T, Bressman SB, Klein C, Ozelius LJ, Riess O, Grundmann K: Expression profiling in peripheral blood reveals signature for penetrance in DYTI dystonia. Neurobiol Dis 2010, 38:192-200.

26. Bradley D, Whelan R, Walsh R, Reilly RB, Hutchinson S, Molloy F, Hutchinson M: Temporal discrimination threshold: VBM evidence for an endophenotype in adult onset primary torsion dystonia. Brain 2009, 132:2327-35.

FI000 Factor 3.0 Recommended

Evaluated by Alfredo Berardelli 17 Nov 2009

27. Vale RD: AAA proteins. Lords of the ring. J Cell Biol 2000, I50: FI3-9.

28. Hanson $\mathrm{PI}$, Whiteheart SW: AAA+ proteins: have engine, will work. Nat Rev Mol Cell Biol 2005, 6:5 19-29.

29. Goodchild RE, Dauer WT: Mislocalization to the nuclear envelope: an effect of the dystonia-causing torsinA mutation. Proc Natl Acad Sci U S A 2004, 10 I:847-52.

FI000 Factor 3.0 Recommended

Evaluated by Phyllis Hanson 20 May 2004

30. Hewett JW, Zeng J, Niland BP, Bragg DC, Breakefield XO: Dystoniacausing mutant torsinA inhibits cell adhesion and neurite extension through interference with cytoskeletal dynamics. Neurobiol Dis 2006, 22:98-III.

31. Giles LM, Chen J, Li L, Chin LS: Dystonia-associated mutations cause premature degradation of torsinA protein and celltype-specific mislocalization to the nuclear envelope. Hum Mol Genet 2008, 17:2712-22.

32. Online Mendelian Inheritance in Man. [www.ncbi.nlm.nih.gov/ sites/entrez?db=omim] 